\title{
ANALISIS PROBLEMATIKA GURU DALAM PEMBELAJARAN DARING PADA PEMBELAJARAN TEMATIK DI SD/MI
}

\author{
Nila $^{1}$, Lathifah Abdiyah ${ }^{2}$, Agus Dwi Prasojo ${ }^{3}$ \\ UIN Sunan Kalijaga Yogyakarta \\ nila9771@gmail.com , lathifahabdiyah00@gmail.com
}

\begin{abstract}
This study aims to explain the problems of online learning for teachers in improving thematic learning in SD/MI during online learning. The research method used in this study is a qualitative research method. Based on the object of study, this research is a literary research or library research. Library research is a research conducted by collecting data, information, and various other data contained in the library. Sources of data used in this study are books, journals, articles, and other scientific works that are relevant to the object of study in this study. The results of the study show that the problems of online learning have an impact on teachers and explain online learning in thematic learning and its problems.
\end{abstract}

Keywords:Online Learning, Problematic, Teacher

\begin{abstract}
Abstrak: Penelitian ini bertujuan untuk menjelaskan problematika pembelajaran daringbagi guru dalam meningkatkan pembelajaran tematik di SD/MI selama pembelajaran daring. Metode penelitian yang digunakan dalam penelitian ini yaitu metode penelitian kualitatif.Berdasarkan objek kajian, penelitian ini termasuk penelitian yang bersifat litere atau kepustakaan (library research). Library research adalah suatu peneltian yang dilakukan dengan cara mengumpulkan data, informasi, dan berbagai macam data-data lainnya yang terdapat dalam kepustakaan. Sumber data yang digunakan dalam penelitian ini yaitu buku, jurnal, artikel, dan karya ilmiah lainnya yang relevan dengan objek kajian pada penelitian ini.Hasil dari penelitian menunjukkan bahwaproblematika pembelajaran online berdampak pada guru dan menjelaskan pembelajaran online pada pembelajaran tematik dan permasalahannya.
\end{abstract}

Kata Kunci:Pembelajaran Daring, Problematika, Guru

FONDATIA : Jurnal Pendidikan Dasar

Volume 5, Nomor 2, September 2021; 210-219

https://ejournal.stitpn.ac.id/index.php/fondatia 


\section{PENDAHULUAN}

Pandemi covid-19 secara tiba-tiba mengharuskan elemen pendidikan untuk melakukan Pembelajaran pada masa pandemi covid-19 mempertahankan pembelajaran secara online. Kondisi saat ini mendesak untuk melakukan inovasi dan adaptasi terkait pemanfaatan teknologi yang tersedia untuk mendukung proses pembelajaran. Praktiknya mengharuskan pendidik maupun peserta didik untuk berinteraksi dan melakukan transfer pengetahuan secara online. Pembelajaran online dapat memanfaatkan platform berupa aplikasi, website, jejaring sosial maupun learning management system. Berbagai platform tersebut dapat dimanfaatkan untuk mendukung transfer pengetahuan yang didukung berbagai teknik diskusi dan lainnya ${ }^{1}$

Pembelajaran tematik di sekolah rendah untuk jenjang sekolah dasar dan sederajat, rencananya tetap akan menggunakan metode tematik integratif. Metode ini sangat baik bagi guru SD dan sederajat. Di dalam kurikulum 2013 dan kurikulum untuk kelas rendah seperti kelas satu, dua, dan tiga sudah menggunakan metode pembelajaran tematik. Dalam metode tematik integratif, materi ajar tidak disampaikan berdasarkan mata pelajarran tertentu, melainkan dalam bentuk tematema yang mengintegrasikan seluruh mata pelajaran Metode ini sudah diterapkan di banyak sekolah. Karena dinilai berhasil, pemerintah lalu mengadopsi dan berencana menerapkan metode ini secara nasional. Metode tematik integratif adalah pembelajaran yang menggunakan tema dalam mengaitkan beberapa materi ajar sehingga dapat memberikan pengalaman bermakna pada siswa ${ }^{2}$

Pemerintah telah mengeluarkan kebijakan tentang Kurikulum 2013. Kebijakan ini antara lain memberi ruang gerak yang luas kepada lembaga pendidikan khususnya SD/MI dalam mengelola sumber daya yang ada, dengan cara mengalokasikan seluruh potensi dan prioritas sehingga mampu melakukan terobosan-terobosan sistem pembelajaran yang lebih inovatif dan kreatif. Salah satu upaya kreatif dalam melaksanakan pembelajaran yang menggunakan kurikulum

\footnotetext{
1 Siregar, Muhammad Yusuf, and Suharian Amiril Akbar. "Strategi Guru Dalam Meningkatkan Kualitas Mengajar Selama Masa Pandemi COVID-19.” At- Tarbawi 12, no. 2 (2020): 180-188.

2 Sutirjo \& Mamik, S I. “Tematik: Pembelajaran Efektif Dalam Kurikulum 2004.” Malang: Bayumedia (2005).
} 
berbasis kompetensi di SD/MI adalah melakukan pembelajaran tematik. Pembelajaran model ini akan lebih menarik dan bermakna bagi anak karena model pembelajaran ini menyajikan tema-tema pembelajaran yang lebih aktual dan kontekstual dalam kehidupan sehari-hari ${ }^{3}$ Namun demikian masih banyak pihak yang belum memahami dan mampu menerapkan model ini secara baik, selain itu juga Pembelajaran Tematik dapat diartikan suatu kegiatan pembelajaran dengan mengintegrasikan materi beberapa mata pelajaran dalam satu tema/topik pembahasan. Pembelajaran tematik merupakan satu usaha untuk mengintegrasikan pengetahuan, keterampilan, nilai, atau sikap pembelajaran, serta pemikiran yang kreatif dengan menggunakan tema.

Pembelajaran Tematik dilakukan dengan maksud sebagai upaya untuk memperbaiki dan meningkatkan kualitas pendidikan, terutama untuk mengimbangi padatnya materi kurikulum. Disamping itu pembelajaran tematik akan memberi peluang pembelajaran terpadu yang lebih menekankan pada partisipasi/keterlibatan siswa dalam belajar. Keterpaduan dalam pembelajaran ini dapat dilihat dari aspek proses atau waktu, aspek kurikulum, dan aspek belajar mengajar ${ }^{4}$ Dalam menerapkan dan melaksanakan pembelajaran tematik, ada beberapa prinsip dasar yang perlu diperhatikan yaitu: (1) bersifat terintegrasi dengan lingkungan, (2) bentuk belajar dirancang agar siswa menemukan tema, dan (3) efisiensi. Agar diperoleh gambaran yang lebih jelas berikut ini akan diurakan ketiga prinsip tersebut. Pembelajaran Tematik memiliki ciri-ciri atau karakteristik sebagai berikut: berpusat pada siswa, Memberikan pengalaman langsung kepada siswa, Pemisahan mata pelajaran tidak begitu jelas, Menyajikan konsep dari berbagai mata pelajaran dalam suatu proses pembelajaran, Bersifat fleksibel, hasil pembelajaran dapat berkembang sesuai dengan minat, dan kebutuhan siswa $^{5}$

Permasalahan yang muncul adalah berkaitan dengan kesiapan sekolah dalam mengapresiasi model pembelajaran tematik sangat beragam. Sebagian sekolah ada yang masih menerapkan model mata pelajaran ketika kegiatan belajar mengajar

3 Hernawan, Asep Herry, and Novi Resmini. "Konsep Dasar Dan Model-Model Pembelajaran Terpadu." Jakarta: Universitas Terbuka (2009).

${ }^{4}$ Sutirjo \& Mamik, S I. “Tematik: Pembelajaran Efektif Dalam Kurikulum 2004.” Malang: Bayumedia (2005).

${ }^{5} \mathrm{Ibid}$ 
dilaksanakan didalam kelas. Hal ini banyak faktor yang mempengaruhinya diantaranya kesiapan guru untuk mengajar kurang memahami model pembelajaran tematik.selain itu juga, situasi dan kondisi di amsa pandemi seperti ini banyak sekali kendala dan permasalahan yang terjadi jaringan atau sinyal, tidak adanya bacaan sumber bagi siswa, kurangnya pengawasan orangtua selama pembelajaran, dan lain sebagainya. Berdasarkan latarbelakang masalah diatas, peneliti tertarik untuk melakukan penelitian terkait dengan strategi guru dalam mengembangkan model dan metode untuk meningkatkan pembelajaran tematik selama pandemi.

\section{METODE PENELITIAN}

Metode penelitian yang digunakan dalam penelitian ini yaitu metode penelitian kualitatif. Metode penelitian kualitatif adalah metode penelitian yang digunakan untuk meneliti pada kondisi obyek alamiah, dimana peneliti adalah sebagai intrumen kunci ${ }^{6}$ Berdasarkan objek kajian, penelitian ini termasuk penelitian yang bersifat litere atau kepustakaan (library research). Library research adalah suatu peneltian yang dilakukan dengan cara mengumpulkan data, informasi, dan berbagai macam data-data lainnya yang terdapat dalam kepustakaan. Sumber data yang digunakan dalam penelitian ini yaitu buku, jurnal, artikel, dan karya ilmiah lainnya yang relevan dengan objek kajian pada penelitian ini.

Teknik pengumpulan data pada penelitian ini adalah dokumentasi. Selanjutnya, untuk mengolah dan menganalisis data, penulis menggunakan metode content analysis yaitu sebuah analisis terhadap kandungan isi. Sumber data yang digunakan dalam penelitian ini yaitu buku, jurnal, artikel, dan karya ilmiah lainnya yang relevan dengan objek kajian pada penelitian ini.

\section{HASIL DAN PEMBAHASAN}

Kebijakan social distancing maupun physical distancing guna meminimalisir penyebaran covid-19 mendorong semua elemen pendidikan untuk mengaktifkan kelas meskipun sekolah tutup. Penutupan sekolah menjadi langkah mitigasi paling

${ }^{6}$ Sugiyono, S. “Memahami Penelitian Kualitatif, Cet.” Ke-12. Bandung: Alfabeta (2016). 
efektif untuk meminimalisir penyebaran wabah pada anak-anak. Solusi yang diberikan yakni dengan memberlakukan pembelajaran di rumah dengan memanfaatkan berbagai fasilitas penunjang yang mendukung. Selama masa pandemi covid-19 pembelajaran di rumah atau online menjadi solusi dalam pembelajaran.

\section{Problematika Pembelajaran OnlineBerdampak pada Guru.}

Pertama, kompetensi guru dalam menggunakan teknologi akan mempengaruhi kualitas program belajar mengajar. Oleh karena itu sebelum diadakan program belajar online sebaiknya para guru diberikan pelatihan terlebih dahulu. Bagi guru muda, mereka menjadi lebih cepat belajar dan menjadi mahir menggunakan teknologi internet atau media sosial sebagai sarana pembelajaran. Namun beberapa guru senior belum sepenuhnya mampu menggunakan perangkat atau fasilitas untuk penunjang kegiatan pembelajaran online dan perlu pendampingan.

Kedua, fasilitas yang mendukung kelnacaran pembelajaran online. Fasilitas ini sangat penting untuk kelancaran proses belajar mengajar khususnya pada pembelajaran online. Seharusnya terlebih dahulu disediakan fasilitas seperti laptop, komputer ataupun handphone yang akan memudahkan guru untuk memberikan materi belajar mengajar secara online.

Ketiga, guru belum memiliki budaya belajar jarak jauh. Sebab selama ini sistem belajar dilaksanakan melalui tatap muka. Guru terbiasa terbiasa berada di sekolah untuk berinteraksi dengan murid-murid, dengan adanya metode pembelajaran jarah jauh membuat para guru perlu waktu untuk beradaptasi dan mereka menghadapi perubahan baru yang secara tidak langsung akan mempengaruhi kualitas pembelajaran.

Adanya wabah covid-19 memaksa para guru harus menggunakan teknologi, sehingga suka tidak suka dan mau tidak mau harus belajar dan siap mengajar melalui jarak jauh dengan menggunakan teknologi. Setiap sekolah menyiapkan alat dan sistem pembelajaran jarak jauh dan melakukan bimbingan teknis kepada para guru agar bisa menggunakan 
teknologi moderen dalam pembelajaran untuk meningkatkan kualitas anak didik di sekolah dasar. Kendala yang dihadapi para guru adalah adanya penambahan biaya pembelian kuota internet bertambah, teknologi online memerlukan koneksi jaringan ke internet dan kuota oleh karena itu tingkat penggunaaan kuota internet akan bertambah dan akan menambah beban pengeluaran guru.

Untuk melakukan pembelajaran online selama beberapa bulan tentunya akan diperlukan kuota yang lebih banyak lagi dan secara otomatis akan meningkatkan biaya pembelian kuota internet. Kompetensi guru dalam memanfaatkan teknologi dan menguasai teknologi untuk pembelajaran dituntut untuk meningkat dengan cepat untuk merespon online home learning. Komunikasi guru dan sekolah dengan orang tua harus terjalin dengan lancar. Artinya, ada pengeluaran tambahan biaya yang harus dibayar oleh guru baik berupa material maupun nonmaterial. ${ }^{7}$ Misalnya pulsa telpon, pulsa untuk akses internet, dan terutama waktu. Salah satu biaya yang otomatis harus dibayar oleh guru adalah guru juga harus memberi technical support pada orang tua apabila terjadi glitches (masalah) dengan baik yang berhubungan dengan teknologi yang langsung digunakan dalam proses pembelajaran maupun setting gawai yang digunakan oleh peserta didik.

Ini akan membiasakan peserta didik untuk mengumpulkan dan mengelola informasi terkait tugas yang diberikan tanpa batasan ruang dan waktu. Hal ini dikarenakan pembelajaran online memungkinkan akses informasi dan pengetahuan dirumah dan dimanapun yang disesuaikan dengan kenyamanan peserta didik. Belajar online menuntut peran pendidik mengevaluasi efektivitas dan disesuaikan dengan kebutuhan belajar. Ini penting dilakukan untuk tetap memenuhi aspek pembelajaran seperti proses pengetahuan, moral, keterampilan, kecerdasan dan estetika.

7 Achmady, Z A. "Kebutuhan Guru Dan Tenaga Kependidikan Serta Peningkatan Kualitas Pendidikan.” Pengarahan Dalam Rangka Rapat Kerja LPTK se-Indonesia (1993): 8-10. 


\section{Pembelajaran Online pada Pembelajaran Tematik dan Permasalahannya}

Google Clasroommemungkinkan guru untuk mengembangkan pembelajaran kreatif. Diskusi dan transfer pengetahuan secara face-tofacelayaknya bertemu melalui beragam platform video teleconference yang banyak tersedia gratis seperti Zoom dan Google Meet. Platform tersebut menjadikan pendidik dan peserta didik untuk bertemu dan berinteraksi. secara virtual dengan fasilitas pesan instan dan kegiatan presentasi. ${ }^{8}$ Aktifitas pembelajaran yang dapat dilakukan mulai dari diskusi, presentasi hingga pemberian tugas.

Ini selaras dengan penelitian Firman dan Rahayu bahwa pembelajaran online melatih kemandirian belajar. Ini akan membutuhkan keterlibatan peserta didik yang lebih besar untuk meningkatkan perilaku belajar observasional. Perilaku tersebut dapat dilakukan dengan membaca, memaknai postingan diskusi dan mendiskusikan video atau konten pembelajaran. Adanya wabah Covid-19 memaksa para guru harus menggunakan teknologi, sehingga suka tidak suka dan mau tidak mau harus belajar dan siap mengajar melalui jarak jauh dengan menggunakan teknologi. Setiap sekolah menyiapkan alat dan sistem pembelajaran jarak jauh dan melakukan bimbingan teknis kepada para guru agar bisa menggunakan teknologi moderen dalam pembelajaran untuk meningkatkan kualitas anak didik di sekolah dasar. Kendala yang dihadapi para guru adalah adanya penambahan biaya pembelian kuota internet bertambah, teknologi online memerlukan koneksi jaringan ke internet dan kuota oleh karena itu tingkat penggunaaan kuota internet akan bertambah dan akan menambah beban pengeluaran guru.

Komunikasi dalam Pembelajaran Online mengingat bahwa perubahan ke pembelajaran online secara tidak langsung berpengaruh pada daya serap peserta didik. Penting untuk diperhatikan yakni

8 Andang. Manajemen Dan Kepemimpinan Kepala Sekolah: Konsep, Strategi Dan Inovasi Menuju Sekolah Efektif. Yogyakarta: Ar-Ruzz Media, 2014. 
komunikasi orang tua dan pendidik untuk mewujudkan kemandirian belajar peserta didik selama masa pandemicovid-19. Ragam manfaat yang diperoleh, tentu memiliki kendala yang dirasakan pendidik maupun peserta didik dalam pembelajaran online. Kendala yang dihadapi yakni kondisi wilayah di Indonesia yang beragam menyebabkan tidak semua wilayah terjangkau oleh layanan internet dan sebaran jaringan internet yang lamban sewaktu-waktu. ${ }^{9}$ Pandemi covid-19 ini mengakibatkan terjadinya perubahan kebijakan secara mendasar dalam dunia pendidikan tanah air. Menteri Pendidikan dan Kebudayaan RI, Nadiem Anwar Makarim telah mengeluarkan beberapa kebijakan untuk mengatur kegiatan pembelaran selama masa pandemi ini.

Hal tersebut dikeluarkan melalui Surat edaran Nomor 4 Tahun 2020, yaitu tentang Pelaksanaan Kebijakan Pendidikan dalam Masa Darurat Penyebaran Coronavirus Disease (covid-19), tertanggal 24 Maret 2020. Secara positif pembelajaran ini sangat membantu keberlangsungan pembelajaran di masa pandemi ini. Guru dan siswa akan tetap aman berada pada tempat atau rumahnya masing-masing tanpa harus keluar rumah dan bertatap muka secara langsung. Namun, merubah pola atau kebiasaan sangatlah sulit, dan merupakan hal wajar ketika terjadi perubahan yang sangat cepat dan tidak terduga. Kebiasaan yang berubah secara signifikan ini misalnya, guru dan siswa sangat mengandalkan perangkat komputer dan jaringan internet, itu yang pertama. ${ }^{10}$

Guru dan siswa harus mampu merubah gaya, strategi atau metode mengajar dan belajar. Guru dan siswa harus mampu merubah gaya komunikasinya selama pembelajaran daring ini. Banyak guru yang tidak memperhatikan bagiaan ini, yaitu kurangnya pemahaman dan penerapan guru dalam berkomunikasi dengan siswanya. Guru biasanya berkomunikasi satu atau dua arah di sekolah, dengan bertatap muka

\footnotetext{
9 Khasanah, Dian Ratu Ayu Uswatun, Hascaryo Pramudibyanto, and Barokah Widuroyekti. "Pendidikan Dalam Masa Pandemi Covid-19." Jurnal Sinestesia 10, no. 1 (2020): 41-48.

10 Andang. Manajemen Dan Kepemimpinan Kepala Sekolah: Konsep, Strategi Dan Inovasi Menuju Sekolah Efektif. Yogyakarta: Ar-Ruzz Media, 2014.
} 
secara secara langsung melakukan diskusi dan latihan secara bersamasama. ${ }^{11}$ Guru akan lebih mudah memberikan pemaparan dan penjelasan suatu materi, sedangkan siswa akan lebih mudah dalam memahami dan berdiskusi langsung kepada gurunya. Dengan kejadian pandemi ini, hal ini menjadi sangat sulit untuk tetap mempertahankan kebiasaan gaya komunikasi guru tersebut. ${ }^{12}$

\section{KESIMPULAN}

Beberapa problematika pembelajaran online berdampak pada guru, diantaranya: pertama, kompetensi guru dalam menggunakan teknologi akan mempengaruhi kualitas program belajar mengajar; kedua, fasilitas yang mendukung kelancaran pembelajaran online. Ketiga, guru belum memiliki budaya belajar jarak jauh. Komunikasi dalam Pembelajaran Online mengingat bahwa perubahan ke pembelajaran online secara tidak langsung berpengaruh pada daya serap peserta didik. Penting untuk diperhatikan yakni komunikasi orang tua dan pendidik untuk mewujudkan kemandirian belajar peserta didik selama masa pandemi covid-19. Ragam manfaat yang diperoleh, tentu memiliki kendala yang dirasakan pendidik maupun peserta didik dalam pembelajaran online. Kendala yang dihadapi yakni kondisi wilayah di Indonesia yang beragam menyebabkan tidak semua wilayah terjangkau oleh layanan internet dan sebaran jaringan internet yang lamban sewaktu-waktu. Guru dan siswa harus mampu merubah gaya, strategi atau metode mengajar dan belajar. Guru dan siswa harus mampu merubah gaya komunikasinya selama pembelajaran daring ini.

${ }^{11}$ Hermino, Agustinus. Kepemimpinan Pendidikan Di Era Globalisasi. Yogyakarta: Pustaka Pelajar, 2014.

12 Suhardiman, Budi. Studi Pengembangan Sekolah. Jakarta: PT Rineka Cipta, 2012. 


\section{DAFTAR PUSAKA}

Achmady, Z A. "Kebutuhan Guru Dan Tenaga Kependidikan Serta Peningkatan Kualitas Pendidikan." Pengarahan Dalam Rangka Rapat Kerja LPTK seIndonesia (1993): 8-10.

Andang. Manajemen Dan Kepemimpinan Kepala Sekolah: Konsep, Strategi Dan Inovasi Menuju Sekolah Efektif. Yogyakarta: Ar-Ruzz Media, 2014.

Hermino, Agustinus. Kepemimpinan Pendidikan Di Era Globalisasi. Yogyakarta: Pustaka Pelajar, 2014.

Hernawan, Asep Herry, and Novi Resmini. "Konsep Dasar Dan Model-Model Pembelajaran Terpadu." Jakarta: Universitas Terbuka (2009).

Khasanah, Dian Ratu Ayu Uswatun, Hascaryo Pramudibyanto, and Barokah Widuroyekti. "Pendidikan Dalam Masa Pandemi Covid-19." Jurnal Sinestesia 10, no. 1 (2020): 41-48.

Siregar, Muhammad Yusuf, and Suharian Amiril Akbar. "Strategi Guru Dalam Meningkatkan Kualitas Mengajar Selama Masa Pandemi COVID-19." AtTarbawi 12, no. 2 (2020): 180-188.

Sugiyono, S. "Memahami Penelitian Kualitatif, Cet." Ke-12. Bandung: Alfabeta (2016).

Suhardiman, Budi. Studi Pengembangan Sekolah. Jakarta: PT Rineka Cipta, 2012.

Sutirjo \& Mamik, S I. “Tematik: Pembelajaran Efektif Dalam Kurikulum 2004." Malang: Bayumedia (2005). 